\title{
Pencegahan Korupsi Pasca Putusan MK Nomor 71/PUU/XIV/2016 Melalui Pendekatan Kebijakan
}

\section{Corruption Prevention After Constitutional Court Decision Number 71/PUU/XIV/2016 Through Policy Approach}

\author{
Yaris Adhial Fajrin; Ach. Faisol Triwiwijaya \\ Fakultas Hukum Universitas Muhammadiyah Malang; \\ yarisroyaadhifa@gmail.com; achfaisolt@yahoo.com \\ 08133354042
}

Abstarak

Korupsi sebagai extra ordinary crime dalam upaya memberantasnya tidak cukup hanya mengandalkan penegakan hukum pidana yang sifatnya represif namun juga harus menggunakan instrument pencegahan. Namun pasca putusan MK Nomor 71/PUU/XIV/2016 aspek pencegahan dalam rangka tindak pidana korupsi mengalami kemunduran dalam tataran regulasi karena putusan tersebut menyatakan tidak memiliki kekuatan hukum mengikat pasal 7 ayat (2) huruf g Undang-undang Nomor 10 Tahun 2016 yang merupakan salah satu regulasi yag bersifat pencegahan tindak pidana korupsi. Aspek pencegahan dalam upaya pemberantasan korupsi memiliki peran strategis karena tidak cukup apabila hanya menggunakan penegakan yang sifatnya represif. Dipandang dari sisi keadilan Pancasila serta politik kriminal putusan MK Nomor 71/PUU/XIV/2016 merupakan anomali ditengah gencarnya agitasi pemberantasan korupsi di Indonesia dan menyebabkan kerugian bagi masyarakat karena dalam tindak pidana korupsi masyarakat adalah korban.

Kata Kunci : Korupsi; Politik Kriminal; Kebijakan Hukum Pidana.

\begin{abstract}
Abstact
Corruption as an extraordinary crime in an attempt to eradicate it is not enough just to rely on criminal law enforcement that are repressive but also must use the instrument of prevention. But after the Constitutional Court decision No. 71 / PUU / XIV / 2016 aspects of prevention in the context of corruption suffered a setback in the level of regulation because the decision states do not have binding legal force of Article 7 paragraph (2) letter g of Law No. 10 of 2016 which is one regulation meant to be the prevention of corruption. Prevention aspects of the eradication of corruption has a strategic role because it is not enough if it only uses that are repressive enforcement. Viewed from the side of Pancasila justice and criminal politics, the Constitutional Court's decision No. 71 / PUU / XIV / 2016 was an anomaly in the midst of the incessant agitation to eradicate corruption in Indonesia and caused losses to the community because in the corruption act the community was a victim.
\end{abstract}


Keyword : Corruption; Criminal Policy; Criminal Law Policy.

\section{A. Latar Belakang}

Pencalonan kepala daerah merupakan salah satu bentuk pengejawantahan sistem demokrasi yaitu melibatkan rakyat di dalam proses pelaksanaanya. Salah satu bentuk demokrasi di tingkat daerah adalah pemilihan kepala daerah baik gubernur, bupati, dan walikota. Melalui mekanise pemilihan kepala daerah sebagai ajang untuk menemukan calon-calon pemimpin daerah yang berintegritas dan bisa mengemban amanah rakyat. ${ }^{1}$ Sudah seharusnya pilihan yang diberikan kepada rakyat untuk dipilih sebagai pemimpin merupakan sosok yang memang layak dan berintegritas tinggi. Salah satu tolak ukur integritas seseorang adalah dengan melihat, apakah ia pernah pernah terlibat dalam suatu tindak pidana ataukah tidak, termasuk juga didalamnya adalah tindak pidana korupsi. Mengingat korupsi merupakan kejahatan berkategori extra ordinary crime, terorganisir, merugikan keuangan atau perekonomian negara, dan pada hakikatnya merupakan kejahatan yang menyerang kepercayaan/amanah yang diberikan terhadap si pelaku.

Demi menghasilkan pemimpin yang berintegritas, individu yang akan mencalonkan sebagai peserta pemilihan kepala daerah harus melalui serangkaian persyaratan dimana diatur di dalam Undang-Undang Nomor 10 Tahun 2016 tentang Perubahan Kedua Atas Undang-Undang Nomor 1 Tahun 2015 Tentang Penetapan Peraturan Pemerintah Pengganti Undang-Undang Nomor 1 Tahun 2014 Tentang Pemilihan Gubernur, Bupati, Dan Walikota Menjadi UndangUndang. Undang-undang tersebut mengatur mengenai syarat untuk menjadi calon, salah satunya yaitu tidak pernah menjadi mantan narapidana. Persyaratan ini dipandang sebagai langkah visioner untuk mencari pemimpin yang terbaik. Namun ketentuan tersebut dilakukan judicial review ke Mahkamah Konstitusi dan melalui putusan nomor 71/PUU/XIV/2016 menyatakan pasal 7 ayat 2 huruf g yang mengatur mengenai persyaratan peserta calon kepala daerah dinyatakan inkonstitutional sepanjang tidak dimaknai tidak pernah sebagai terpidana berdasarkan putusan pengadilan yang telah memperoleh kekuatan hukum tetap karena melakukan tindak

\footnotetext{
${ }^{1}$ Ridho Imawan Hanafi, Pemilihan Langsung Kepala Daerah Di Indonesia: Beberapa Catatan Kritis Untuk Partai Politik. Jurnal Penelitian Politik Volume 11 No. 2 Desember 2014. 2
} 
pidana yang diancam dengan pidana penjara 5 tahun/lebih, kecuali terhadap terpidana yang melakukan tindak pidana kealpaan dan tindak pidan politik atau bagi mantan terpidana telah secara terbuka dan jujur mengemukakan kepada publik bahwa yang bersangkutan mantan terpidana. Artinya bahwa, salah satu syarat seseorang boleh mencalonkan diri adalah dia tidak pernah menjadi narapidana yang dihukum penjara di atas lima tahun. Atau dengan kata lain, bagi seseorang yang pernah menjadi narapidana dengan hukuman penjara di bawah lima tahun, boleh untuk mencalonkan diri.

Data Komisi Pemberantasan Korupsi (KPK) menunjukkan adanya tren penjatuhan sanksi pidana penjara di bawah lima tahun, bagi terpidana korupsi, sebagaimana diungkapkan Indonesia Coruption Watch menunjukkan vonis perkara korupsi dari tahun 2014 hingga tahun 2018 sebanyak 84 kepala daerah yang disidangkan di tingkat pertama, 41 diantaranya dihukum ringan, yakni dihukum 1 sampai 4 tahun. Sehingga keluarnya putusan MK tersebut, serta dengan memperhatikan tren tersebut, memberikan kekhawatiran bahwa mantan narapidana korupsi sebagian besar dapat mencalonkan diri. Terlebih lagi, jenis sanksi pidana berupa pencabutan hak politik bagi narapidana korupsi masih minim dijatuhkan bagi terpidana korupsi. Salah satu sebabnya karena, jenis sanksi tersebut merupakan bagian dari jenis pidana tambahan yang bersifat fakultatif menurut Undang-undang 31 Tahun 1999 tentang pemberantasan tindak pidana korupsi Pasal 18. Kalau pun sanksi ini dijatuhkan, justru lebih sering diberikan kepada terpidana korupsi yang dijatuhi sanksi penjara di atas lima tahun, seperti perkara LHI, dan AU. ${ }^{2}$

Alasan yang demikian menjadi dasar argumentasi penulis bahwa keluarnya putusan MK tersebut berimplikasi negatif terhadap upaya pencegahan korupsi, serta usaha/cita-cita mewujudkan pemerintahan yang baik dan bersih. Mengingat fakta bahwa dari tahun 2014 hingga tahun 2018 sebanyak 84 kepala daerah terjerat kasus korupsi dan perkaranya naik sampai ketingkat pemeriksaan di pengadilan. ${ }^{3}$ Selain itu, terbukanya peluang bagi mantan narapidana korupsi untuk mencalonkan diri, dapat memberikan kemungkinan tertutupnya kesempatan bagi orang-orang atau individu-individu yang belum pernah tercatat sebagai narapidana untuk mencalonkan diri. Apalagi di Indonesia ada kecenderungan seseorang yang pernah menjadi

\footnotetext{
${ }^{2}$ Lihat putusan No. 1195 K/Pid.Sus/2014 dan Putusan No. 1261 K/Pid.Sus/2015

${ }^{3}$ https://www.beritasatu.com/nasional/528035/icw-hukuman-bagi-kepala-daerah-korup-masih-ringan.
} 
narapidana untuk mencalonkan diri kembali sebagai pejabat publik. Hal tersebut tergambarkan dari data Indonesia Corruption Watch (ICW) mengenai mantan narapidana korupsi mencalonkan sebagai anggota legislatif ${ }^{4}$ :

\begin{tabular}{|l|l|}
\hline \multicolumn{1}{|c|}{ PARPOL } & \multicolumn{1}{c|}{$\begin{array}{c}\text { JULAH CALEG MANTAN } \\
\text { KORUPTOR }\end{array}$} \\
\hline Gerindra & 3 Orang \\
\hline Golkar & 4 Orang \\
\hline Garuda & 2 Orang \\
\hline Berkarya & 1 Orang \\
\hline PKS & 1 Orang \\
\hline Perindo & 1 Orang \\
\hline PAN & 3 Orang \\
\hline Hanura & 2 Orang \\
\hline Demokrat & 4 Orang \\
\hline PKP & 2 Orang \\
\hline & 23 Orang \\
\hline
\end{tabular}

Penjelasan Umum Undang-undang Nomor 31 Tahun 1999 tentang Pemberantasan Tindak Pidana Korupsi, alinea pertama, menyebutkan bahwa untuk mewujudkan masyarakat Indonesia yang adil, makmur, dan sejahtera tersebut, perlu secara terus menerus ditingkatkan usaha-usaha pencegahan dan pemberantasan tindak pidana pada umumnya serta tindak pidana korupsi pada 2019.html.

\footnotetext{
${ }^{4}$ https://www.merdeka.com/politik/ini-daftar-49-mantan-koruptor-yang-maju-jadi-caleg-di-pemilu-
} 
khususnya. Artinya disitu bahwa adanya korelasi antara usaha pencegahan korupsi dengan usaha mewujudkan masyarakat Indonesia yang berkeadilan. Adil dalam hal ini berarti keadilan berdasarkan Pancasila, sebagai landasan idiil Bangsa Indonesia. Pancasila sendiri beberapa kali menyebutkan kata "adil” di dalam rumusannya, yaitu sila ke-2 dan sila ke-5. Dimana itu sebagai gambaran bahwa persoalan keadilan menjadi suatu hal yang paling esensi dalam pandangan Pancasila.

Sehingga keluarnya putusan MK Nomor 71/PUU-XIV/2016 selain dipandang melemahkan upaya pencegahan tindak pidana korupsi, juga berimplikasi terhadap nilai-nilai keadilan, khususnya keadilan sosial masyarakat Indonesia yang terkandung dalam Pancasila. Maka dari itu, melalui tulisan ini, penulis mencoba membedah keberlakuan Pasal 7 ayat (2) huruf g Undang-undang Nomor 10 tahun 2016 tentang Perubahan Kedua Atas Undang-Undang Nomor 1 Tahun 2015 Tentang Penetapan Peraturan Pemerintah Pengganti Undang-Undang Nomor 1 Tahun 2014 Tentang Pemilihan Gubernur, Bupati, Dan Walikota Menjadi Undang-Undang tersebut dalam kaitannya dengan upaya pencegahan tindak pidana korupsi dan usaha mewujudkan pemerintahan yang baik, dari perspektif keadilan sosial yang berkepancasilaan, pasca keluarnya putusan MK Nomor 71/PUU-XIV/2016 dalam rangka itu lah, maka penulis mengangkat dua buah permasalahan, yaitu:

1. Bagaimana konsep keadilan yang berkepancasilaan dalam upaya pemberantasan korupsi ?

2. Bagaimana implikasi putusan MK Nomor 71/PUU-XIV/2016 ditinjau dari Keadilan Pancasila dan Politik Kriminal?

\section{B. Metode Penelitian}

Metode yang akan digunakan dalam penelitian ini adalah metode pendekatan yuridis normatif, yaitu dilakukan dengan cara mengkaji peraturan perundang-undangan yang berlaku dan diterapkan terhadap permasalahan hukum tertentu. ${ }^{5}$ Dalam hal ini Undang-undang nomor 31 tahun 1999 tentang pemberantasan tindak pidana korupsi jo undang-undang nomor 20 tahun 2001 tentang perubahan atas undang-undang nomor 31 tahun 1999 tentang

\footnotetext{
${ }^{5}$ Abdulkadir Muhammad, Hukum dan Penelitian Hukum, (Bandung: PT Citra Aditya, 2004), 57
} 
pemberantasan tindak pidana korupsi, undang-undang nomor 10 tahun 2016 tentang Perubahan Kedua Atas Undang-Undang Nomor 1 Tahun 2015 Tentang Penetapan Peraturan Pemerintah Pengganti Undang-Undang Nomor 1 Tahun 2014 Tentang Pemilihan Gubernur, Bupati, Dan Walikota Menjadi Undang-Undang serta putusan MK Nomor 71/PUUXIV/2016. Metode analisis bahan hukum yang digunakan dalam penelitian ini adalah metode analisis kualitatif, suatu analisis yang dilakukan dengan memahami dan menyusun bahan hukum yang telah diperoleh secara sistematis, sehingga diperoleh gambaran mengenai masalah atau keadaan yang diteliti. ${ }^{6}$

\section{Pembahasan}

\section{Konsep keadilan yang berkepancasilaan dalam upaya pemberantasan korupsi}

Pembangunan nasional bagi Indonesia merupakan pencerminan kehendak untuk terus-menerus meningkatkan kesejahateraan dan kemakmuran rakyat Indonesia secara adil dan merata, serta mengembangkan nilai-nilai kehidupan masyarakat dan penyelenggaraan Negara yang maju dan demokratis berdasarkan Pancasila sebagai wujud pengamalan semua sila Pancasila secara serasi dan sebagai kesatuan yang utuh. ${ }^{7}$ Guna mencapai pembangunan nasional yang relatif ideal, hukum memiliki peranan penting sebagai sarana perubahan sosial yang dibuat untuk menggerakkan masyarakat agar sesuai dengan irama dan tuntutan pembangunan dalam segala aspek kehidupan berbangsa dan bernegara. ${ }^{8}$ Menanggapi upaya pembangunan hukum tersebut, Sunaryati Hartono ${ }^{9}$, mengemukakan bahwa untuk mempercepat proses kegiatan pembangunan hukum agar terbentuk dan berfungsinya sistem hukum nasional yang mantap berdasarkan Pancasila dan UUD 1945.

Pasal 2 Undang-Undang Nomor 12 Tahun 2011 Tentang Pembentukan Peraturan Perundang-undangan mengamanatkan bahwa sistem perundang-undangan harus bersumber

\footnotetext{
${ }^{6}$ Soerjono Soekanto dan Sri Mamudji, Penelitian Hukum Normatif Suatu Tinjauan Singkat, (Jakarta: PT Raja Grafindo Persada, 2004), 50

7 Ginandjar Kartasasmita, Pembangunan untuk Rakyat : Memadukan Pertumbuhan dan Pemerataan, (Jakarta : CIDES, 1996) 26

${ }^{8}$ Sebagaimana pendapat dari Mochtar Kusumaatmadja, bahwa di Indonesia hukum dalam pembangunan berfungsi sebagai sarana pembaruan masyarakat. Selain itu hukum sebagai tata kaidah dapat berfungsi sebagai sarana untuk menyalurkan arah kegiatan-kegiatan masyarakat ke tujuan yang dikehendaki oleh perubahan yang terencana. Lihat : Mochtar Kusumaatmadja, 1976, Hubungan Antara Hukum dengan Masyarakat: Landasan Pikiran, Pola, dan Mekanisme Pelaksanaan Pembaruan Hukum (Jakarta: BPHN-LIPI, 1976) 9

${ }^{9}$ Sunaryati Hartono, Kebijakan Pembangunan Hukum Jangka Panjang Tahap Kedua (Jakarta: majalah BPHN, 1994) No 1.
} 
pada Pancasila sebagai sumber dari segala sumber hukum. Pembentuk undang-undang tentu memiliki retio legis menempatkan Pancasila sebagai sumber dari segala sumber hukum. Sebab Pancasila ditempatkan sebagai dasar dan ideologi negara serta sekaligus dasar filosofis negara. Terlebih lagi jika berbicara persoalan keadilan, maka Pancasila jelas menjadi sumber utama menggali nilai-nilai keadilan yang selaras dengan kehidupan berbangsa dan bertanah air masyarakat Indonesia. Nilai-nilai keadilan tergambarkan dalam rumusan Pancasila, dimana secara tersurat tercantum di sila ke-2 dan sila ke-5, serta secara tersurat di sila pertama dan sila ke-4.

Memaknai keadilan Pancasila harus dilakukan secara integrative antar sila, yang mana muaranya adalah keadilan sosial sebagai sila penutup. Hari Chand menyebut keadilan sosial (social justice) dengan nama lain yaitu keadilan distributif. ${ }^{10}$ Pendapat Chand tersebut didasarkan pada pemikiran bahwa keadilan sosial tergambarkan pada regulasi mengenai pendistribusian sumber daya yang dimiliki oleh negara untuk kepentingan masyarakat/rakyat secara merata. Sehingga tolak ukur keadilan sosial/keadilan distributif adalah pemerataan pendistribusian sumber daya milik negara untuk kepentingan kesejahteraan masyarakat luas. ${ }^{11}$ Pendapat tersebut tidak jauh berbeda dengan apa yang dikemukakan oleh Ir. Soekarno (Presiden pertama Indonesia) sebagai salah seorang founding father Republik Indonesia, yang disampaikannya dalam pidato hari lahirnya Pancasila. ${ }^{12}$

"maka oleh karena itu, jikalau kita memang betul-betul mengerti, mengingat, mencintai rakyat Indonesia, marilah kita terima prinsip socielrechtvaardigheid ini, yaitu buka saja persamaan politik, sudara-saudara,

${ }^{10}$ Istilah "keadilan sosial" sebagai suatu frasa pertama kali diperkenalkan oleh Luigi Taparelli d'Azeglio tahun 1840. Keadilan sosial berhubungan dengan kegiatan sosial dari masyarakat dimana individu bagian dari anggota masyarakat. Dalam: Rosadi, Otong, Quo Vadis, Hukum Ekologi dan Keadilan Sosial, Dalam Perenungan Pemikiran (Filsafat) Hukum, (Bantul Thafa Media, 2012) 108-109.

11 Jika peneliti bandingkan dengan pendapat O. Notohamidjojo yang bertolak ukur dari pendapat Aristoteles mengenai keadilan distributif, maka dapat ditarik sebuah premis bahwa keadilan distributif haruslah mengacu pada pendistribusian sumber daya yang dimiliki oleh negara secara merata dan proporsional demi tujuan mensejaterahkan hidup seluruh masyarakat. Merata artinya bahwa sumber daya Negara tersebut haruslah terdistribusikan secara menyeluruh ke masyarakat luas, serta harus dengan memperhatikan skala proporsionalitas, sehingga hak masyarakat untuk mendapatkan kesejahteraan dari berbagai aspek kehidupan dapat dipenuhi oleh Negara sebagai organisasi masyarakat terluas/terbesar.

12 Yudi Latif, Negara Paripurna : Historisitas, Rasionalitas, dan Aktualitas Pancasila, (Jakarta : PT. Gramedia Pustaka Utama, 2011) 582. 
tetapi pun di atas lapangan ekonomi harus mengadakan persamaan, artinya kesejahteraan bersama yang sebaik-baiknya".

guna membumikan keadilan sosial dalam kerangka Pancasila maka keadilan sosial haruslah bertolak ukur pada persamaan dan kesetaraan diberbagai bidang. ${ }^{13}$

Mengenai istilah keadilan distributif sebagaimana yang dikemukakan oleh Hari Chand di atas, mengingatkan penulis pada pendapat Aristoteles, yang membagi keadilan menjadi dua bentuk yaitu keadilan distributif dan keadilan komutatif. ${ }^{14}$ Keadilan distributif menekankan kepada keadilan yang tidak sama, artinya pembagian adil didasarkan kepada prestasi untuk mendapat keadilan, sedangkan keadilan komutatif, memberikan keadilan sama banyaknya tanpa melihat keadaan-keadaan tertentu. Kemudian mengenai bentuk keadilan yang lebih teknis Aristoteles memberikan tiga prinsip mencapai keadilan, dimana bila ketiga prinsip ini dimanifestasikan dalam hukum, akan menciptakan keadilan secara universal. Ketiga prinsip tersebut adalah:

1) Prinsip honeste vivere, adalah prinsip hidup tidak tercela. Artinya hukum harus mengatur agar manusia tidak hidup dalam ketercelaan dengan menjalankan suatu keburukan.

${ }^{13}$ Sila ke-5 Pancasila mengenai "keadilan sosial" mengandung makna bahwa Negara Indonesia merupakan suatu Negara yang bertujuan mewujudkan suatu kesejahteraan bagi seluruh warganya/rakyatnya. Atau dengan kata lain Indonesia adalah Negara welafare state, yaitu Negara yang memiliki prinsip untuk mencapai kesejahteraan dalam kehidupan kebangsaan dan kenegaraan. Hal tersebut secara eksplisit terkandung dalam pembukaan UUD 1945, “ ... Negara melindungi segenap bangsa dan seluruh tumpah darah Negara, memajukan kesejahteraan umum, mencerdaskan kehidupan bangsa ... ". Nilai keadilan yang terkandung di dalam sila ke-5 tersebut haruslah terwujud dalam kehidupan bersama (kehidupan sosial). Keadilan tersebut didasari dan dijiwai oleh hakikat keadilan kemanusiaan, yaitu keadilan dalam hubungan manusia dengan dirinya sendiri, dengan manusia lainnya, dengan bangsa dan negaranya, serta dengan Tuhannya. Hal tersebut memiliki konsekuensi nilai-nilai keadilan yang harus terwujud dalam hidup bersama, yang meliputi:

a. keadilan distributif: yaitu suatu hubungan keadilan antara Negara dengan warganya, dimana Negara yang memiliki kewajiban memenuhi keadilan tersebut kepada semua warganya secara merata dengan memperhatikan hak dan kewajiban warganya;

b. keadilan legal/bertaat: yaitu suatu hubungan keadilan antara warga Negara terhadap negaranya, dimana dalam hal ini warga lah yang memiliki kewajiban memenuhi keadilan dalam wujud ketaatannya terhadap peraturan perundang-undangan yang berlaku;

c. keadilan komutatif: yaitu hubungan keadilan antar warga Negara secara timbali balik.

Lihat: Kaelan, Pendidikan Pancasila, Pendidikan Untuk Mewujudkan Nilai-nilai Pancasila, Rasa Kebangsaan, dan Cinta Tanah Air, Edisi Revisi Kesepuluh, (Yogyakarta: Paradigma, 2014).hal. 76-77 dan 177.

${ }^{14}$ Bernard L Tanya et.al. Teori Hukum. (Bantul, Genta Publishing, 2013) 41 
2) Prinsip alterum non laedere, prinsip tidak mengganggu orang. Dimana hukum merupakan insturumen agar masyarakat yang diaturnya tetap dalam patern yang tidak melanggar hak orang lain, guna mewujudkan sosial defence.

3) Prinsip sun quique tribuere, prinsip ketiga ini berhubungan dengan prinsip kedua, yaitu apa yang telah menjadi hak dari orang lain agar terciptanya tatanan masyarakat yang sejahtera atau terciptanya sosial walfare. ${ }^{15}$

Jikan pendapat Aristoteles tersebut lebih disederhanakan lagi, maka akan sinkron dengan apa yang dikemukakan oleh John Rawls ${ }^{16}$ mengenai keseimbangan antara kepentingan pribadi dan kepentingan bersama. Dimana hukum berperan untuk meminimalisir dan mengantisipasi adanya benturan antara dua kepentingan tersebut, sehingga akan ada jaminan terhadap stabilitas hidup manusia. Disitulah sedikit tergambarkan kaitan antara hukum dan keadilan, dimana keadilan merupakan bagian dari ontologi hukum yang sumbernya adalah nilai. Keadilan dan kebenaran merupakan turunan dari nilai sebagai hakikat hukum yang sifatnya universal dan kodrati.

Keseimbangan antara kepentingan pribadi dan kepentingan bersama sebagai prinsip keadilan yang dikemukakan oleh Rawls di atas, senada dengan pendapat Notonagoro dalam memandang Pancasila. Dimana menurut beliau dengan Pancasila maka manusia ditempatkan keluhuran harkat dan martabatnya sebagai makhluk Tuhan YME dengan kesadaran untuk mengemban kodratnya sebagai makhluk pribadi sekaligus makhluk sosial, dimana kebahagiaan hidup akan tercapai jika didasarkan pada keselarasan dan keseimbangan, baik dalam hidup manusia sebagai pribadi, dalam hubungannya dengan masyarakat, dalam hubungannya dengan alam, dalam hubungannya dengan bangsa lain, dalam hubungannya dengan Tuhan YME, maupun dalam mengejar kemajuan lahiriah dan rohani. Prinsip keseimbangan, atau yang oleh Ter Haar disebut dengan istilah evenwicht, merupakan gambaran hubungan masyarakat Indonesia dengan semua hal yang bersifat keduniaan maupun yang bersifat kerohaniahan, sebagai syarat mutlak untuk mewujudkan

\footnotetext{
${ }^{15}$ Ibid. 42

${ }^{16}$ Otong Rosadi, Quo Vadis, Hukum Ekologi ... Op.cit. 99-103
} 
kehidupan yang bahagia dan harmonis. ${ }^{17}$ Sehingga jika ditarik ke dalam tataran yang lebih konkrit, maka sebagaimana pendapat Yudi Latif, mengenai komitmen keadilan sosial menurut alam pemikiran Pancasila tersebut memiliki dimensi yang luas, sehingga tolak ukurnya terletak pada peran negara. ${ }^{18}$ Menurut beliau, prinsip keadilan sosial dalam kerangka Pancasila maka negara haruslah berperan dalam kerangka: mewujudkan relasi yang adil di semua tingkat sistem kemasyarakatan, dan pengembangan struktur yang menyediakan kesetaraan kesempatan. ${ }^{19}$ Meninjau dan mengkomparasi pemikiranpemikiran filsuf barat mengenai keadilan, dengan apa yang terkandung dalam Pancasila, menurut penulis esensinya adalah sama. Sebagaimana dikatakan Ulpianus, bahwa adil merupakan kemauan yang sifatnya tetap dan terus menerus sebagai ukuran memberikan kepada setiap orang sebagaimana mestinya. ${ }^{20}$

Lebih lanjut Notonagoro mengkaitkan persoalan keadilan sosial dengan didasarkan pada nilai-nilai ketuhanan. Dimana "keadilan berdasarkan tuntutan Tuhan" menegaskan prinsip persamaan (non-diskriminatif), objektif (tidak subjektif), prinsip tak pilih kasih dan tidak berpihak. Sedangkan jika dikaitkan dengan prinsip kemanusiaan, maka keadilan sosial yang berparadigmakan kemanusiaan akan hadir bila bangsanya menjalankan cara berhukum dengan tenggang rasa, toleran, solidaritas, humanis, rasa malu, dan kasih sayang. Kebebasan dipahami bukan sebagai kebebasan individualistik melainkan kebebasan bernilaikan keadaban, sehingga Pancasila memberikan watak kemanusiaan tidak semata hanya adil tapi juga penuh keadaban. Adab dalam hal ini tidak semata diartikan sebagai kesantunan saja, melainkan juga kearifan. ${ }^{21}$ Sebagaimana yang dikutip oleh Teguh Prasetyo dari istilah Jawa, ngewongke uwong atau dalam bahasa Indonesia adalah memanusiakan manusia. ${ }^{22}$

${ }^{17}$ Tidak jauh berbeda dengan Ter Haar, Supomo menyatakan bahwa alam tradisonal Indonesia bersifat kosmis, meliputi segala-galanya sebagai kesatuan dan totalitas. Imam Sudiyat menggambarkan antara keseimbangan, keselarasan, dan keserasian antara dunia lahir dan dunia ghaib, antara golongan manusia sebagai keseluruhan dan orang-seorang, antara persekutuan dan masyarakat. Lihat: Muladi. Lembaga Pidana Bersyarat, (Bandung: P.T. Alumni, 1985) 55-56.

${ }^{18}$ Kaelan, Pendidikan Pancasila ... Op.Ci.t, 59-60.

${ }^{19}$ Lihat: Yudi Latif, Negara Paripurna..... Op.Cit, 585.

${ }^{20}$ Teguh Prasetyo. Keadilan Bermartabat Perspektif Teori Hukum. (Bandung, Nusa Media, 2018) 101

${ }^{21}$ Faisal, Ilmu Hukum, Sebuah Kajian Kritis, Filsafat, Keadilan, dan Tafsir, (Yogyakarta: Thafa Media, 2015) 72.

${ }^{22}$ Teguh Prasetyo. Keadilan Bermartabat... Op.cit. 
Keadilan Pancasila merupakan keadilan yang tidak hanya bersifat kebendaan, tapi lebih dari itu, dimana keadilan Pancasila adalah keadilan vital dan kerohanian. Notonegoro membagi keadilan Pancasila kedalam tiga nilai. Pertama, nilai material merupakan segala sesuatu yang berguna secara jasmani bagi manusia. Kedua, nilai vital berguna untuk melaksanakan aktivitas. Ketiga, nilai kerohanian yang bersumber dari akal manusia berupa kebenaran, keindahan bersumber dari rasa manusia, kebaikan moral dan nilai kerohanian bersumber kepada ajaran agama maupun kepercayaan lainnya. ${ }^{23}$ Menurut penulis dalam konteks keadilan Pancasila adalah keadilan guna mewujdukan cita-cita kesejahteran sosial (sosial walfare) melalui wujud sosial defence. Keadilan perspektif Pancasila ini, sehubungan dengan peberantasan tindak pidana korupsi tidak semata-mata kepada adil secara material namun juga nilai vital dan nilai kerohanian sebagai penjaga keseimbangan. Pancasila sebagai landasan filsafat keadilan dalam sistem hukum Indonesia dapat menjadi acuan pemberantasan korupsi di Indonesia manakala tindakan dalam upaya itu mampu menciptakan keseimbangan serta kesejahteraan masyarakat.

\section{Implikasi Putusan MK Nomor 71/PUU-XIV/2016 Terhadap Mantan Narapidana Korupsi Ditinjau Dari Perpsektif Keadilan Pancasila dan Poltik Kriminal}

Putusan MK Nomor 71/PUU-XIV/2016 membawa arah baru dalam kontestasi pemilihan kepala daerah. Melalui putusan tersebut mantan pelaku tindak pidana korupsi memiliki hak untuk mengikuti kontestasi pemilihan kepala daerah. Sebelum putusan MK aquo pasal 7 ayat (2) huruf g Undang-Undang Nomor 10 Tahun 2016 tentang Perubahan Kedua Atas Undang-Undang Nomor 1 Tahun 2015 Tentang Penetapan Peraturan Pemerintah Pengganti Undang-Undang Nomor 1 Tahun 2014 Tentang Pemilihan Gubernur, Bupati, Dan Walikota Menjadi Undang-Undang mengatur pembatasan hak politik mantan pelaku tindak pidana untuk tidak dapat menjadi peserta pemilihan kepala daerah, yaitu seorang kepala daerah nantinya tidak boleh pernah berstatus sebagai narapidana. Aturan tersebut merupakan salah satu ihtiyar menemukan pemimpin yang berintegritas dimana pasal aquo merupakan pengejawantahan standart moral yang hidup dalam masyarakat. Dimana sebagai seorang

${ }^{23}$ Muladi. Lembaga Pidana Bersyarat... Op.cit. 55 
pimpinan tertinggi di suatu daerah, maka orang tersebut haruslah orang yang dipandang masyarakat sebagai sosok yang "sempurna" dan bersih, sehingga mampu untuk menjalankan fungsi jabatannya dengan amanah dan dipercaya oleh rakyat, serta menjadi contoh/tauladan bagi masyarakat yang dipimpinnya. ${ }^{24}$ Selain itu, menurut penulis ratio decendi putusan tersebut sebagai bentuk proteksi dari kemungkinan mantan terpidana akan melakukan tindak pidana dikemudian hari.

Namun pasca putusan MK aquo standart moral tersebut mengalami pergeseran, dimana mantan terpidana yang diputus dengan pidana penjara di bawah lima tahun dapat mencalonkan diri sebagai calon kepala daerah. Ketentuan tersebut secara umum berlaku, bagi mantan narapidana apapun (termasuk mantan narapidana korupsi), kecuali mantan narapidana kejahatan seksual dan narkotika. ketentuan tersebut (putusan MK) dipandang adil, jika melihat dari perspektif hak warga negara, khususnya warga negara yang ingin mencalonkan diri, sebagaimana yang dilindungi oleh konstitusi. Tetapi dalam kehidupan bernegara, yang tidak kalah penting untuk diperhatikan adalah hak warga negara secara umum, yang dalam hal ini adalah hak yang dimiliki oleh rakyat/masyarakat. Dimana rakyat/masyarakat juga memiliki hak untuk memilih calon pemimpin di daerah mereka yang benar-benar layak dan patut untuk menduduki jabatan publik tersebut. Sehingga idealnya pemilihan umum itu merupakan sarana untuk memilih orang yang terbaik diantara sekian banyak orang yang baik, untuk memimpin daerah.

Korupsi merupakan salah satu jenis tindak pidana, yang diatur di Undang-undang Nomor 31 Tahun 1999 tentang Pemberantasan tindak pidana korupsi Jo. Undang-undang Nomor 20 Tahun 2001 tentang Perubahan atasa undang-undang nomor 31 tahun 1999 tentang pemberantasan tindakk pidana korupsi. Sebelumnya, perbuatan-perbuatan yang saat ini diatur di dua undang-undang korupsi tersebut, telah diatur terlebih dahulu di KUHP, yang tersebar di berbagai pasal, diantaranya: Pasal 209, Pasal 210, Pasal 418, Pasal 419 dan Pasal 420. Ketentuan-ketentuan tersebut tercantum di Buku II KUHP mengenai Kejahatan. Hal

${ }^{24}$ Salah satu upaya non penal yang tidak kalah pentingnya adalah mengenai perencanaan kesehatan mental masyarakat (community planning mental health). Korupsi yang dilakukan oleh penyelenggara negara maupun pejabat publik, menimbulkan krisis ketauladanan di masyarakat. Masyarakat justru diperlihatkan berbagai bentuk penyalahgunaan kekuasaan, diantaranya adalah korupsi. Lihat: Ali Zaidan, Kebijakan Kriminal (Jakarta, Sinar Grafika, 2016) 121. 
tersebut membuktikan bahwa korupsi sudah sejak lama dinilai sebagai perbuatan jahat (kejahatan). Dimana segala sesuatu yang dinilai jahat, sudah barang tentu ada nilai-nilai ketidakadilan disana. Atau dengan kata lain, kejahatan selain merupakan suatu perbuatan bernilai jahat, juga didalamnya mengandung nilai-nilai yang menciderai keadilan. Arugmentasi penulis mengenai hubungan kejahatan dan ketidakadilan dilandaskan kepada fungsi hukum pidana, menurut Vos fungsi hukum pidana untuk melawan kelakuan-kelakuan tidak normal. Lebih lanjut menurut Hart fungsi hukum pidana melindungi warga masyarakat dari tindakan yang merugikan. ${ }^{25}$ Terlihat reaksi hukum pidana atas tindakan jahat yang mengambil hak masyarakat sehingga Kejahatan secara mutadis mutandis bersandingan dengan ketidakadilan yaitu hak masyarakat untuk hidup secara aman, damai dan tentram yang tidak dapat tercapai. Dalam konteks tindak pidana korupsi sebagai bentuk kejahatan yang merugikan keuangan Negara $^{26}$ merupakan bentuk ketidakadilan sebab korupsi menghambat proses penyejahteraan masyarakat yang berhubungan dengan keuangan negara.

Ketika korupsi dipandang sebagai perbuatan yang menyerang keuangan atau perekonomian negara (lihat Pasal 3 Undang-undang tipikor, maka ada hak negara yang diambil oleh koruptor. Jika kita menggunakan definisi negara sebagai kumpulan masyarakat/rakyat sebagaimana pendapat dari Aristoteles yang beranggapan berdirinya negara dimaksudkan untuk kepentingan warga negara supaya warga negara dapat hidup baik dan bahagia. ${ }^{27}$ Maka sudah barang tentu ada hak rakyat/masyarakat agara dapat hidup bahagia yang dilanggar oleh koruptor yang menyebabkan tidak bahagianya warga negara. Sehingga dapat diambil benang merah disini, bahwa pada hakikatnya rakyat/masyarakat lah yang menjadi korban akibat adanya suatu tindak pidana korupsi.

Menempatkan rakyat/masyarakat sebagai korban tindak pidana korupsi tidak dapat dilepaskan dari Definisi "korban" sendiri di Pasal 1 angka 2 Undang-undang Nomor 13

${ }^{25}$ Eddy O.S Hiariej, Prinsip-prinsip Hukum Pidana. (Yogyakarta, Cahaya Atma Pustaka, 2014)

${ }^{26}$ Menurut Lilik Mulyadi kerugian tersebut secara sederhana dapat disebutkan sebagai perbuatan yang mengakibatkan menjadi rugi atau menjadi berkurang, diartikan sebagai menjadi ruginya keuangan negara atau berkurangnya keuangan negara. Lihat : Kristwan Genova Damanik, Antara Uang Pengganti Dan Kerugian Negara Dalam Tindak Pidana Korupsi. (Jurnal Masalah-masalah Hukum, Jilid 45 No. 1, Januari 2016) 5

${ }^{27}$ Muhammad Junaidi, Ilmu Negara sebuah konstruksi ideal negara hukum. (Malang, Setara Press, 2016) $19-20$ 
Tahun 2006 tentang Perlindungan Saksi dan Korban, menyebutkan bahwa korban merupakan "seseorang yang mengalami penderitaan fisik, mental, dan/atau kerugian ekonomi yang diakibatkan oleh suatu tindak pidana". Disamping definisi secara yuridis menurut Arif Gosita korban adalah mereka yang menderita jasmaniah dan rohaniah sebagai akibat tindakan orang lain yang mencari pemenuhan kepentingan diri sendiri atau orang lain, yang bertentangan dengan kepentingan hak asasi pihak yang dirugikan. ${ }^{28}$ Sedangkan menurut Muladi, korban merupakan orang-orang yang baik secara individual maupun kolektif telah menderita kerugian, termasuk kerugian fisik atau mental, emosional, ekonomi, atau gangguan substansial terhadap hak-haknya yang fundamental, melalui perbuatan atau komisi yang melanggar hukum pidana di masing-masing Negara, termasuk penyalahgunaan kekuasaan $^{29}$. Mendasarkan dari ketentuan tersebut dan dari berbagai pendapat ahli serta teori-teori viktimologi, penulis mendefinisikan korban sebagai seseorang yang menanggung akibat dari terjadinya suatu kejahatan, berupa:

a) Penderitaan psikis, seksual, fisik, sosial; ${ }^{30}$ dan/atau

b) Penderitaan dan/atau kerugian ekonomi. ${ }^{31}$

Penderitaan merupakan suatu akibat nyata yang dapat diukur dan dibuktikan. Tetapi penderitaan sendiri, juga berdampak terhadap rasa/perasaan yang dimiliki oleh korban yang itu tidak tampak secara nyata. Wilayah rasa/perasaan ini lah yang hanya dapat disentuh dengan pendekatan keadilan. Sehingga upaya penegakan hukum tidak semata bertujuan untuk menghukum (meresosialisasi dan mengintegrasi ke tengah-tengah kehidupan sosial masyarakat) pelaku atau mencegah kejahatan semata, tetapi yang lebih esensi adalah

${ }^{28}$ Arif Gosita, Maslah korban kejahatan, (CV Akademika Pressindo, Jakarta, 2005) 63

${ }^{29}$ Muladi,.HAM Dalam Perspektif Sistem Peradilan Pidana. (Bandung, Refika Aditama, 2005) 108

${ }^{30}$ Dalam Kamus Besar Bahasa Indonesia (KBBI), "menderita" diartikan sebagai "menanggung sesuatu yang tidak menyenangkan; kesengsaraan", sedangkan "penderitaan" diartikan sebagai "keadaan yang menyedihkan yang harus ditanggung". Sehingga penulis merumuskan bahwa akibat yang ditimbulkan dari adanya kejahatan berupa kondisi atau keadaan yang tidak menyenangkan (kesengsaraan) yang menyerang fisik, psikis, seksual, sosial, maupun mental seseorang. Jika dikaitkan dengan Undang-undang Nomor 23 Tahun 2004 tentang Penghapusan Kekerasan Dalam Rumah Tangga, maka penderitaan yang diterima korban dapat terjadi karena adanya kekerasan dan/atau ancaman kekerasan.

${ }^{31}$ Dalam hal ini penulis membedakan antara unsur akibat berupa "penderitaan ekonomi" dengan "kerugian ekonomi". Penderitaan ekonomi dapat ditafsirkan sebagai wujud keadaan/kondisi yang memunculkan sesuatu derita kehidupan secara luas terhadap korban. Sedangkan kerugiann ekonomi, ditafsirkan sebagai adanya kekayaan milik korban yang tidak terwujud sebagai akibat dari perbuatan pelaku. Sehingga kerugian ekonomi tidak selalu mewujudkan penderitaan ekonomi, sehingga unsur "penderitaan ekonomi" sifatnya lebih luas dibandingkan unsur "kerugian ekonomi". 
mengembalikan nilai-nilai keadilan yang terkoyak akibat adanya suatu kejahatan atau tindak pidana. Tidak terkecuali dalam hal tindak pidana korupsi, dimana yang terserang akibat adanya tindak pidana tersebut tidak hanya persoalan kerugian negara (keuangan atau perekonomian), tetapi juga nilai-nilai kepercayaan masyarakat/rakyat yang diberikan kepada si pelaku dalam suatu bentuk amanah. Sehingga kembalinya kerugian negara, atau menghukum pelaku korupsi, hal tersebut tidak serta merta mengembalikan kepercayaan rakyat/masyarakat yang telah diciderai oleh mantan narapidana korupsi. Bahkan, memaafkan pelaku kejahatan, tidak serta merta akan mengembalikan kepercayaan kepadanya. Sehingga perlu waktu dan upaya dari diri si mantan terpidana untuk mengembalikan kembali kepercayaan yang telah hilang akibat ia melakukan suatu kejahatan. Jika penulis analogikan, dimana mantan terpidana kasus penculikan bayi, walaupun ia telah menjalani pidana dan telah diterima di tengah-tengah masyarakat, hal tersebut tidak serta merta mengembalikan kepercayaan para orang tua kepada mantan terpidana ini untuk mengurus dan merawat anak/bayi mereka.

Penjelasan Umum Undang-undang Nomor 31 Tahun 1999 tentang Pemberantasan Tindak Pidana Korupsi, alinea pertama, menyebutkan bahwa untuk mewujudkan masyarakat Indonesia yang adil, makmur, dan sejahtera tersebut, perlu secara terus menerus ditingkatkan usaha-usaha pencegahan dan pemberantasan tindak pidana pada umumnya serta tindak pidana korupsi pada khususnya. Penjelasan tersebut dapat dimaknai bahwa guna mewujudkan cita-cita keadilan (keadilan sosial, sebagaimana sila ke-5 Pancasila), kemakmuran, dan kesejahteraan, maka dapat menempuh upaya pencegahan dan pemberantasan tindak pidana, salah satunya dan yang paling penting adalah tindak pidana korupsi. Upaya pencegahan identik dengan upaya prefentif sebagai salah satu cara antisipatif agar korupsi tidak terjadi. Sedangkan pemberantasan identik dengan upaya-upaya penegkan hukum (hukum pidana), melalui sarana peradilan. Jika mengacu pada adagium bahwa hukum pidana sebagai ultimum remidium (obat terakhir) dalam penyelesaian suatu perkara, maka lebih tepat jika pendekatan pencegahan-lah yang menjadi solusi terbaik. Selain itu, rumusan Penjelasan di undang-undang tersebut juga menggambarkan bahwa upaya pencegahan dalam tindak pidana korupsi dapat selaras dan serasi dengan nilai-nilai keadilan, khususnya keadilan sosial, sebagaimana yang diamanahkan oleh Pancasila. 
Korupsi yang semakin marak di Indonesia dan cenderung menjadi sebuah "budaya" telah berakibat negatif, baik langsung maupun tidak, terhadap kesejahteraan dan kemakmuran rakyat. Dimana sumber daya ekonomi yang dikuasai negara yang sejatinya digunakan dan difungsikan sebesar-besarnya untuk kepentingan rakyat, justru disalahgunakan oleh adanya korupsi. Sehingga berdampak pada tidak meratanya distribusi kesejahteraan dan kemakmuran bagi rakyat Indonesia. Hal itu lah yang mendasarkan pendapat penulis, bahwa korupsi sejatinya tidak hanya sekedar suatu kejahatan terhadap keuangan atau perekonomian negara semata, tetapi juga telah menyerang nilai-nilai keadilan sosial serta nilai-nilai kemanusiaan yang adil dan beradab sebagaimana yang telah diamanahkan oleh Pancasila. Sehingga, jika memandang kejahatan/tindak pidana sebagai suatu bentuk gangguan terhadap keseimbangan (evenwichtstoring), keselarasan, dan keserasian, dalam kehidupan masyarakat yang mengakibatkan kerusakan individual maupun masyarakat, maka hukum pidana (melalui sarana penalisasi) merupakan upaya untuk memulihkan kembali rusaknya keseimbangan, keserasian, dan keselearasan sebagai akibat dari suatu tindak pidana korupsi. $^{32}$

Jika dikaitkan dengan persoalan hak politik mantan terpidana korupsi, di dalam hukum positif Indonesia saat ini mengenal adanya sanksi pencabutan hak politik, yang diletakkan sebagai bentuk sanksi tambahan. Tetapi itu merupakan upaya terakhir sebagai wujud pencegahan sekaligus wujud penegakan hukum bagi terpidana korupsi, sebagaimana adagium ultimum remidium dalam hukum pidana. Sehingga pembatasan syarat calon kepala daerah, yang tidak boleh berstatus sebagai terpidana (diantaranya terpidana korupsi) sebagaimana ketentuan Pasal 7 ayat (2) huruf g Undang-undang nomor 10 tahun 2016 tentang Perubahan Kedua Atas Undang-Undang Nomor 1 Tahun 2015 Tentang Penetapan Peraturan Pemerintah Pengganti Undang-Undang Nomor 1 Tahun 2014 Tentang Pemilihan Gubernur, Bupati, Dan Walikota Menjadi Undang-Undang, sejatinya merupakan langkah di

${ }^{32}$ Lihat: Muladi, 1985, Lembaga ... Op.cit., 60-61. Bandingkan dengan pendapat Bushar Muhammad mengenai delik adat. Dimana delik adat merupakan suatu perbuatan sepihak dari seorang atau kumpulan perorangan, mengancam atau menyinggung atau mengganggu keseimbangan dalam kehidupan persekutuan, bersifat materiil atau immaterial, terhadap orang seorang atau terhadap masyarakat berupa kesatuan tindakan atau perbuatan yang demikian mengakibatkan suatu reaksi adat yang dipercayainya dapat memulihkan keseimbangan yang telah terganggu, antara lain dengan berbagai jalan dan cara, dengan pembayaran adat berupa barang, uang, mengadakan selamatan, memotong hewan besar/kecil dll. Lihat: Bushar Muhammad, Pokok-pokok Hukum Adat, (Jakarta, Pradnya Paramita, 1981) 61. 
luar hukum pidana dalam mewujudkan tujuan pencegahan korupsi guna menciptakan pemerintahan yang baik dan bersih. Keluarnya putusan MK 71/PUU-XIV/2016 tersebut, turut berimplikasi negatif (melemahkan) terhadap upaya pencegahan tindak pidana korupsi di Indonesia. Sehingga jika dikaitkan dengan persoalan keadilan, maka putusan MK tersebut dinilai juga turut menciderai nilai-nilai keadilan sosial yang selaras dengan upaya pencegahan tindak pidana korupsi sebagaimana ketentuan pada Penjelasan umum Alinea pertama Undang-undang Nomor 31 Tahun 1999 tentang Pemberantasan Tindak Pidana Korupsi. Terlebih lagi jika melihat fakta saat ini, dimana sebagian besar terpidana korupsi dijatuhi hukum di bawah lima tahun penjara, tanpa disertai dengan sanksi pencabutan hak politik. Justru sanksi pencabutan hak politik diberikan kepada terpidana korupsi yang mendapatkan sanksi penjara di atas lima tahun, seperti perkara LHI dan AU.

Guna mengembalikan nilai-nilai keadilan sosial tersebut, maka perlu ada upaya yang dapat dipakai. Diantaranya adalah melalui pendekatan kebijakan, baik itu kebijakan penanggulangan kejahatan (criminal policy) dan kebijakan hukum pidana (penal policy). Politik kriminal sendiri merupakan bagian dari kebijakan sosial, menurut Sudarto politik kriminal adalah suatu usaha yang rasional dari masyarakat dalam menanggulangi kejahatan. Terlihat peran dari politik kriminal sebagai serangkaian usaha dalam bentuk rekayasa melalui hukum dengan tujuan penanggulangan kejahatan. ${ }^{33}$ Sementara Marc Ancel Merumuskan kebijakan kriminal adalah kontrol secara rasional terhadap kejahatan oleh masyarakat. G. Peter Hoefnagels lebih jelas dalam memaknai kebijakan kriminal yaitu merupakan ilmu tentang reaksi dalam menghadapi kejahatan, menaggulangi kejahatan, merancang tingkah laku untuk penanggulangan kejahatan. Upaya penanggulangan kejahatan pada hakikatnya merupakan bagian integral dari upaya perlindungan masyarakat (social defence) dan upaya untuk mencapai kesejahteraan (social welfare) ${ }^{34}$ sehingga tujuan utama

${ }^{33}$ Rekayasa melalui hukum seperti dikatakan oleh Rosecoupond adalah ramalan yang berakibat kepada perubahan-perubahan sosial dalam artian tingkah laku menggunakan instrument hukum. Lihat : Harpani Matnuh, Law as a Tool of Social Engineering. (Advances in Social Science, Education and Humanities Research, volume 147; 2017) 119

${ }^{34}$ Dey Ravena dan Kristian, Kebijakan Kriminal (Jakarta, Kencana, 2017) 116 
dari politik kriminal adalah untuk memberikan perlindungan masyarakat serta untuk mencapai kesejahteraan masyarakat. ${ }^{35}$

Salah satu pendekatan yang dapat dilakukan dalam upaya penanggulangan kejahatan (criminal policy) adalah melalui keterpaduan antara upaya penanggulangan kejahatan tersebut dengan upaya "penal" dan "non-penal". ${ }^{36}$ Dimana upaya penal/non-penal tersebut dapat dicapai melalui otoritas hukum pidana. Sehingga hukum pidana perlu pula mengikuti perkembangan kejahatan melalui upaya pembaruan hukum pidana (penal reform). Disini jelas hubungan antara ketiganya, yaitu pembaharuan hukum pidana merupakan bagian dari kebijakan/politik hukum pidana (penal policy) sebagai salah satu upaya penanggulangan kejahatan melalui pendekatan kebijakan (criminal policy). Hal tersebut senada dengan yang dikemukakan Sudarto bahwa hukum pidana hendaknya dilibatkan dalam usaha mengatasi segi-segi negatif dari perkembangan masyarakat/modernisasi (seperti: kejahatan), maka hendaknya dilihat dalam hubungan keseluruhan politik kriminal, yang merupakan bagian integral dari rencana pembangunan nasional. ${ }^{37}$ Begitu juga pendapat Barda Nawawi Arief, yang menjelaskan bahwa pembaharuan hukum pidana dapat berorientasi kepada kebijakan sosial yang pada hakikatnya adalah bagian dari upaya untuk mengatasi masalah-masalah sosial (termasuk masalah kemanusiaan), serta berorientasi pada kebijakan kriminal sebagai upaya perlindungan masyarakat. ${ }^{38}$

Kongres Perserikatan Bangsa-bangsa (PBB) ke-5 BULAN September tahun 1975 yang diadakan di Geneva Swiss yang membahas mengenai Criminal Legislation, Judicial Procedurs and Other Forms of Social Control in the Prevention of Crime, menyebutkan bahwa salah satu kejahatan yang harus mendapatkan perhatian khusus, diantaranya adalah

35 Tujuan akhir politik kriminal mencapai kesejahteraan masyarakat dalam konteks Indonesia secara tegas tertuang didalam anelia ke-4 pembukaan Undang-Undang Dasar Negara Republik Indonesia Tahun 1945. Kesejahteraan sosial ditandai dengan terpenuhinya kebutuhan hidup masyarakat sehingga masyarakat bisa mencapai kualitas kehidupan yang baik disegala segi kehidupan. Sebagaimana yang penulis kutip dari ketentuan pada Undang-undang Nomor 11 Tahun 2009 tentang Kesejahteraan Sosial Lihat : Dey Ravena dan Kristian, Kebijakan Kriminal... Ibid. 88

${ }^{36}$ Barda Nawawi Arief, Bunga Rampai Kebijakan Hukum Pidana (Perkembangan Penyusunan Konsep KUHP Baru), Edisi Kedua, (Cetakan Ke-3, Jakarta: Kencana, 2011,) 6.

${ }^{37}$ Dey Ravena dan Kristian, Kebijakan .... Op.cit 140

${ }^{38}$ Ibid 142 
organized crime, White Collar Crime (WCC), dan korupsi. ${ }^{39}$ Lebih lanjut pada kogres PBB ke-6 tahun 1980 di Caracas, juga masih menekankan pada kejahatan-kejahatan tersebut sebagai bentuk kejahatan penyalahgunaan kekuasaan dan bersifat transnasional. ${ }^{40}$ Disamping memperhatikan berbagai kecenderungan perkembangan kejahatan (crime trend) seperti yang dikemukakan kongres PBB ke-5 dan ke-6, pada Kongres PBB ke-7 di Milan tahun 1985 mulai memperhatikan persoalan korban kejahatan sebagai bagian dari kebijakan kriminal. Korban dipandang tidak hanya individual, tetapi dalam konteks yang lebih luas, diantaranya adalah korban dari penyalahgunaan kekuasaan. Penyalahgunaan kekuasaan dalam hal ini tidak hanya dalam penyalahgunaan kewenangan hukum, tetapi juga penyalahgunaan kekuasaan ekonomi ${ }^{41}$. Dari keseluruhan uraian singkat tersebut, dapat ditarik benang merah, bahwa persoalan perkembangan kejahatan (diantaranya adalah korupsi dan kejahatan penyalahgunaan kekuasaan) dan korban haruslah masuk di dalam bagian kebijakan sosial negara-negara anggota kongres, termasuk Indonesia. Kebijakan sosial, atau yang oleh Barda Nawawi Arief disebut dengan istilah kebijakan pembangunan nasional, didalamnya termasuk juga mengenai kebijakan kriminal. ${ }^{42}$

Kebijakan penanggulangan kejahatan tidak akan berarti jika kebijakan sosial atau kebijakan pembangunan justru menimbulkan faktor-faktor kriminogen atau viktimogen. Pembangunan pada hakikatnya tidak bersifat kriminogen, selama hasil-hasil pembangunan tersebut didistribusikan secara pantas dan adil kepada semua rakyat serta menunjang seluruh kondisi sosial. ${ }^{43}$ Penanggulangan kejahatan dilakukan secara integral dengan memfokuskan pada upaya preventif/kuasatif, yaitu dengan menanggulangi "sebab dan kondisi". 44 Mengenai kebijakan pembangunan nasional Bangsa Indonesia, penulis mengacu pada beberapa ketentuan perundang-undangan yang secara hirarki merupakan turunan dari UUD 1945 sebagai landasan konstitusi, yaitu Undang-undang Nomor 17 Tahun 2007 tentang Rencana Pembangunan Jangka Panjang Nasional Tahun 2005 - 2025, dan Undang-undang 2003) 131

${ }^{39}$ M. AriefAmrullah. Pencucian Uang dan Kejahatan Terorganisir. (Jurnal Hukum. No. 22 Vol 10. Januari

${ }^{40} \mathrm{Ibid}$

${ }^{41}$ Barda Nawawi Arief, Bunga Rampai Kebijakan Hukum Pidana (Perkembangan Penyusunan Konsep KUHP Baru)... Op.cit. 19

${ }^{42}$ Ibid. 6.

${ }^{43}$ Ibid. $9-10$

${ }^{44}$ Ibid. 22 
Nomor 25 Tahun 2004 tentang Sistem Perencanaan Pembangunan Nasional. Pembangunan nasional sendiri diartikan sebagai upaya yang dilaksanakan oleh semua komponen bangsa dalam rangka mencapai tujuan bernegara, sebagaimana yang diatur di Pasal 1 angka 2 Undang-undang Nomor 25 Tahun 2004. Tujuan bernegara dalam hal sebagaimana termaktub di dalam Pembukaan UUD 1945 alinea ke-4, yaitu:

“...untuk membentuk suatu pemerintah negara Indonesia yang melindungi segenap bangsa Indonesia dan seluruh tumpah darah Indonesia dan untuk memajukan kesejahteraan umum, mencerdaskan kehidupan bangsa, dan ikut melaksanakan ketertiban dunia yang berdasarkan kemerdekaan, perdamaian abadi dan keadilan sosial, maka disusunlah kemerdekaan kebangsaan Indonesia itu dalam suatu Undang-Undang Dasar negara Indonesia, yang terbentuk dalam suatu susunan negara Republik Indonesia yang berkedaulatan rakyat dengan berdasar kepada : Ketuhanan Yang Maha Esa, kemanusiaan yang adil dan beradab, persatuan Indonesia, dan kerakyatan yang dipimpin oleh hikmat kebijaksanaan dalam permusyawaratan/perwakilan, serta dengan mewujudkan suatu keadilan sosial bagi seluruh rakyat Indonesia." (garis bawah oleh penulis).

Berdasarkan korelasi berbagai rumusan tersebut, dapat digambarakan pembangunan nasional harus didasarkan pada aspek keadilan sosial. Sehingga dalam upaya pencegahan dan penanggulangan kejahatan dalam rangka mensukseskan pembangunan nasional, perlu mendasarkan kepada dasar keadilan sosial. Lebih lanjut di Pasal 2 ayat (3) Undang-undang 25 Tahun 2004 tentang Sistem Perencanaan Pembangunan Nasional, menjelaskan bahwa Sistem Perencanaan Pembangunan Nasional diselenggarakan berdasarkan Asas Umum Penyelenggaraan Negara, yang salah satu asasnya adalah Asas "kepentingan umum" yaitu asas yang mendahulukan kesejahteraan umum dengan cara yang aspiratif, akomodatif, dan selektif. $^{45}$ Jika dikaitkan dengan persoalan pemberantasan tindak pidana korupsi

45 Bagian Penjelasan Pasal 2 ayat (3), yang dimaksud dengan "Asas Umum Penyelenggaraan Negara" adalah meliputi: 1. Asas "kepastian hukum" yaitu asas dalam negara hukum yang mengutamakan landasan peraturan perundang-undangan, kepatutan, dan keadilan dalam setiap kebijakan Penyelenggara Negara; 2. Asas "tertib penyelenggaraan negara" yaitu asas yang menjadi landasan keteraturan, keserasian, dan keseimbangan dalam pengendalian penyelenggaraan Negara; 3. Asas "kepentingan umum" yaitu asas yang mendahulukan kesejahteraan umum dengan cara yang aspiratif, akomodatif, dan selektif; 4. Asas "keterbukaan" yaitu asas yang membuka diri terhadap hak masyarakat untuk memperoleh informasi yang benar, jujur, dan tidak diskriminatif tentang penyelenggaraan negara dengan tetap memperhatikan perlindungan atas hak asasi pribadi, golongan, dan rahasia Negara; 5. Asas "proporsionalitas" yaitu asas yang mengutamakan keseimbangan antara hak dan kewajiban Penyelenggara Negara; 6. Asas "profesionalitas" yaitu asas yang mengutamakan keahlian yang berlandaskan kode etik dan ketentuan peraturan perundang-undangan; dan 7. Asas "akuntabilitas" yaitu asas yang menentukan bahwa 
sebagaimana yang termaktub di Penjelasan Umum Undang-undang Nomor 31 Tahun 1999 tentang Pemberantasan Tindak Pidana Korupsi, alinea pertama, menyebutkan bahwa untuk mewujudkan masyarakat Indonesia yang adil, makmur, dan sejahtera tersebut, perlu secara terus menerus ditingkatkan usaha-usaha pencegahan dan pemberantasan tindak pidana pada umumnya serta tindak pidana korupsi pada khususnya. Sehingga semakin tampak arah kebijakan integral antara kebijakan sosial dengan kebijakan kriminal, khususnya dalam kaitannya dengan pemberantasan tindak pidana korupsi. Yaitu untuk mewujudkan pembangunan nasional yang mampu memberikan kesejahteraan bagi rakyat Indonesia berdasarkan nilai-nilai keadilan sosial, maka salah satunya adalah dengan mencegah dan menanggulangi berbagai bentuk kejahatan yang menyerang kepentingan umum, salah satunya adalah kejahatan korupsi sebagai kejahatan yang bersifat terorganisir dan bahkan transnasional. Selain itu disini juga tampak korelasi antara tujuan pembangunan nasional, pencegahan tindak pidana korupsi, dan persoalan keadilan sosial, dimana antara ketiganya ini berkaitan satu dengan lainnya.

Lebih lanjut menurut Barda Nawawi Arief dalam kaitannya dengan penal policy, bahwa harus ada keterpaduan antara upaya penanggulangan kejahatan (dan pencegahan kejahatan, pen.) melalui sarana hukum pidana (penal policy) dengan sarana di luar hukum pidana (non penal policy). ${ }^{46}$ Dimana sebelum keluarnya putusan MK 71/PUU-XIV/2016, dalam rangka pencegahan tindak pidana korupsi dalam kaitan hak politik seseorang, mengenal adanya dua pendekatan. Pertama, pendekatan non penal, yaitu dengan adanya pembatasan bagi mantan terpidana (tidak terkecuali pula adalah korupsi) untuk mecalonkan diri, sebagaimana ketentuan Pasal 7 ayat (2) huruf g Undang-undang nomor 10 tahun 2016 tentang Perubahan Kedua Atas Undang-Undang Nomor 1 Tahun 2015 Tentang Penetapan Peraturan Pemerintah Pengganti Undang-Undang Nomor 1 Tahun 2014 Tentang Pemilihan Gubernur, Bupati, Dan Walikota Menjadi Undang-Undang. Kedua adalah melalui sarana penal, yaitu melalui pemberian sanksi pidana tambahan berupa pencabutan hak politik dalam jangka

setiap kegiatan dan hasil akhir dari kegiatan Penyelenggara Negara harus dapat dipertanggungjawabkan kepada masyarakat atau rakyat sebagai pemegang kedaulatan tertinggi negara sesuai dengan ketentuan peraturan perundangundangan.

${ }^{46}$ Barda Nawawi Arief, Bunga Rampai Kebijakan Hukum Pidana (Perkembangan Penyusunan Konsep KUHP Baru)... Op.cit 6. 
waktu tertentu bagi terpidana korupsi. Secara konsep sebenarnya hal tersebut telah memenuhi cita-cita integralisasi antara kebijakan sosial, kebijakan kriminal, dan kebijakan hukum pidana dalam hal upaya pencegahan tindak pidana korupsi. Walaupun dalam praktek masih banyak sekali terjadii ketidaksesuain dengan konsep tersebut. Tetapi dengan keluarnya putusan MK tersebut, dipandang melemahkan upaya integralisasi dalam hal pencegahan tindak pidana korupsi. Dimana hal tersebut sekaligus menciderai nilai-nilai keadilan sosial sebagaimana yang menjadi dasar mencapai tujuan pembangunan nasional bangsa Indonesia.

Maka dari itu, pasca terbitnya putusan MK 71/PUU-XIV/2016 tersebut dalam hal pembatasan hak politk seorang mantan terpidana khususnya korupsi, perlu ada upaya reintegrasi antara kebijakan sosial, kebijakan kriminal, dan kebijakan hukum pidana. Sebagaimana yang diamanatkan oleh Undang-undang Nomor 31 Tahun 1999 tentang Pemberantasan Tindak Pidana Korupsi, dimana salah satu upaya mewujudkan masyarakat yang sejahtera, adil, dan makmur adalah dengan melakukan upaya pencegahan dan pemberantasan korupsi, maka penulis mencoba mengelaborasi kedua hal tersebut.

a. Upaya pencegahan

Berkaitan dengan hak politik seseorang terpidana, kebijakan yang telah dilakukan adalah melalui dua sarana. Yaitu pertama sarana non penal, dengan memberikan larangan terhadap mantan terpidana (termasuk mantan terpidana korupsi) untuk mencalonkan diri, dan kedua sarana penal, dengan memberikan putusan pencabutan hak politik dengan jangka waktu tertentu kepada terpidana korupsi. Keluarnya putusan MK tersebut, memberikan kesempatan kepada mantan terpidana korupsi yang dihukum dan telah menjalani pidana di bawah lima tahun untuk dapat mencalonkan diri. Ketika usaha non penal bagi mantan terpidana korupsi yang dihukum penjara di bawah lima tahun sudah tidak ada pasca keluarnya putusan MK tersebut, maka digunakanlah upaya penal. Mekanismenya adalah dengan memberikan putusan pencabutan hak politik bagi terpidana korupsi yang mendapatkan sanksi penjara di bawah lima tahun. Hal tersebut, saat ini dipandang masih sangat minim dijatuhkan, karena sanksi pencabutan hak poltik ini merupakan jenis sanksi tambahan, yang pada kenyataannya justru lebih sering dijatuhkan kepada terpidana korupsi yang 
mendapatkan sanksi penjara di atas lima tahun. Sehingga Mahkamah Agung perlu memberikan informasi melalui produk hukum yang mengikat secara internal kepada para hakim pemeriksa perkara korupsi, untuk lebih mengupayakan penjatuhan sanksi pencabutan hak politik terhadap terpidana korupsi yang dijatuhi sanksi penjara di bawah lima tahun.

Pembatasan hak politk bagi mantan terpidana korupsi melalui sarana penal maupun non penal tersebut, selain bertujuan sebagai pencegahan korupsi, juga merupakan perwujudan nilai-nilai keadilan sosial guna mewujudkan kesejahteraan masyarakat Indonesia melalui pembangunan pemerintahan yang baik dan bersih. Unsur utama keadilan sosial menurut Pancasila adalah mengenai kesetaraan kesempatan, dan keseimbangan. Kesetaraan kesempatan artinya adalah bahwa semua warga negara Indonesia berhak atas hak politk, yaitu untuk memilih dan dipilih. Khusus hak untuk dipilih, semua warga negara pun berhak atas hak tersebut. Tetapi hal tersebut berkorelasi dengan hak warga negara lainnya untuk memilih yang terbaik diantara pilihan yang baik. Apabila masayarakat/rakyat diberikan pilihan yang "cacat" secara moralitas, maka itu berimplikasi terhadap tertutupnya kesempatan bagi warga negara lainnya yang masih bersih (tidak memiliki riwayat kriminal) untuk mencalonkan diri, yang itu sama saja dengan membiarkan rakyat untuk memilih pilihan yang diantaranya tidak lah baik. Kemudian mengenai keseimbangan, adalah bahwa mengutamakan kepentingan yang lebih luas daripada sekedar kepentingan individu/pribadi. Putusan MK 71/PUU-XIV/2016 lebih melihat aspek hak pribadi warga negara. Tetapi yang harus diutamakan adalah hak keseluruhan warga negara dalam hal mendapatkan pilihan yang baik untuk memilih yang terbaik. Jika penulis boleh analogikan adalah seperti ini: jika dalam tataran praktek seorang masyarakat/ rakyat ketika melamar pekerjaan lebih sering mensyaratkan melampirkan SKCK (Surat Keterangan Catatan Kepolisian) atau Surat Keterangan Kelakuan Baik yang didalamnya menjelaskan apakah seseorang pernah terlibat tindakan kriminal atau tidak, dimana ketika dia pernah terlibat maka ia tidak dapat diterima dalam suatu pekerjaan. Esensi dari contoh tersebut adalah bahwa persoalan catatan kriminal (seseorang pernah dipidana/tidak) masih menjadi tolak ukur normal dalam 
memberikan pekerjaan atau posisi tertentu kepada seseorang. Apalagi untuk suatu jabatan publik, sebagai pimpinan di daerah.

Dapat pula dengan melakukan upaya untuk mengubah ketentuan Pasal 7 ayat (2) huruf g Undang-undang nomor 10 tahun 2016 tentang Perubahan Kedua Atas Undang-Undang Nomor 1 Tahun 2015 Tentang Penetapan Peraturan Pemerintah Pengganti Undang-Undang Nomor 1 Tahun 2014 Tentang Pemilihan Gubernur, Bupati, Dan Walikota Menjadi Undang-Undang. Salah satu poin yang harus diubah adalah dengan mensejajarkan tindak pidana korupsi dengan tindak pidana kekerasan seksual anak dan bandar narkotika. Seperti yang diketahui pada bagian penjelasan Pasal 7 ayat (2) huruf g menyatakan:

"Yang dimaksud dengan "mantan terpidana" adalah orang yang sudah tidak ada hubungan baik teknis (pidana) maupun administratif dengan menteri yang menyelenggarakan urusan pemerintahan di bidang hukum dan hak asasi manusia, kecuali mantan terpidana bandar narkoba dan terpidana kejahatan seksual terhadap anak." (garis bawah oleh penulis)

Artinya adalah bahwa, dengan adanya ketentuan pengecualian tersebut, menutup kemungkinan bagi mantan terpidana Bandar narkoba dan kejahatan seksual anak untuk mencalonkan diri, tanpa harus melihat ketentuan pengecualian di undang-undang maupun tanpa harus melihat berapa lama jangka waktu sanksi penjara yang dijatuhkan. Sebab korupsi memiliki ciri atau karakter yang sama dengan dua kejahatan tersebut. Korupsi dan narkoba merupakan sama-sama kejahatan terorganisir (organized crime) dan bersifat extra ordinary crime, bahkan dapat bersifat transnasional crime. Selain itu, kedua kejahatan tersebut pun memiliki korban yang luas dan massif. Sedangkan antara korupsi dengan kejahatan seksual anak, sama-sama menyerang nilai-nilai moral yang dianut oleh masyarakat Indonesia; Korupsi menyerang nilai kepercayaan/amanah yang diberikan kepada pelaku (penghianatan), sedangkan kekerasan seksual anak menyerang nilai-nilai kesusilaan.

b. Upaya Penegakan

Upaya penegakan ini berkaitan erat dengan upaya penggunaan/ penerapan hukum pidana. Tetapi dalam kerangka cita-cita pembaruan hukum pidana Nasional yang 
tergambarkan di Rancangan KUHP Nasional mengenai tujuan pemidanaan, menjelaskan bahwa penegakan hukum pidana ini tidak terlepas dan menjadi satu kesatuan dengan tujuan pencegahan dalam upaya pengayoman masyarakat. ${ }^{47}$ Sehingga memenjarakan seorang koruptor bukan menjadi hal utama, dimana yang utama dan yang terpenting adalah bagaimana kerugian negara akibat korupsi dapat kembali. Meminimalkan sanksi penjara bagi terpidana korupsi sebagai langkah meresosialisasi dan mereintegrasi pelaku korupsi, dengan mengedepankan sanksi berupa perampasan aset hasil korupsi dan pencabutan hak politk. Khusus untuk sanksi perampasan aset hasil korupsi, hal dapat dikedepankan sebagai upaya pemberantasan sekaligus upaya pencegahan yang memberikan nilai keadilan sosial bagi masyarakat dan keuntungan bagi negara. Aset-aset hasil korupsi yang dirampas dan dikembalikan ke negara, kemudian dapat didistribusikan secara merata untuk kepentingan kesejahteraan rakyat sebagaimana amanat konstitusi dan Pancasila.

Upaya pemberantasan korupsi diatas mencerminkan dua aspek politik kriminal dari Hoefnagels yaitu melalui pencegahan dan penegakan dengan konsekuensi pendekatan yakni pada penegakan sifatnya repressive sedangkan pencegahan pendekatannya adalah preventif dengan menggunakan instrument lain diluar hukum pidana. Pendekatan yang diberikan oleh Hoefnagel berkorelasi dengan pendapat dari Barda Nawawi Arief mengenai tujuan dari kebijakan kriminal berupa sosial defence dan sosial walfare. Antara pendekatan penal dan non penal menurut penulis adanya hubungan integral antara keduanya yaitu adanya sifat saling backup antara kedua pendekatan karena apabila hanya mengandalkan tindakan represif menurut Muladi tidak dapat diharapkan mengingat penegakan hukum pidana dan pengenaan sanksinya bersifat individual. Sehingga antara tindakan preventif dan represif harus sama-sama diperhatikan dalam upaya pemberantasan kejahatan sebagai bagian dari politik/kebijakan kriminal, dalam konteks penulisan ini peberantasan tindak pidana korupsi.

\section{Kesimpulan}

${ }^{47}$ Lihat dan bandingkan dengan Pasal 54 ayat (1) huruf a RKUHP Nasional: pemidanaan bertujuan untuk mencegah dilakukannya tindak pidana dengan menegakkan norma hukum demi pengayoman masyarakat. 
Pemberantasan tindak pidana korupsi tidak dapat dilepaskan dari politik/kebijakan kriminal berupa pencegahan dan penegakan hukum. Kedua aspek politik/kebijakan kriminal dalam sistem hukum Indonesia diejawantahkan didalam peraturan perundang-undangan. Produk perundang-undangan haruslah berjalan linier dengan cita-cita bangsa Indonesia sebagaimana terdapat didalam Pancasila. Pemberantasan tindak pidana korupsi harus memperhatikan masyarakat sebagai korban artinya kebijakan-kebijkan dalam rangka pemberantasan tindak pidana korupsi dalam sejumlah regulasi harus pro terhadap rakyat baik ranah pencegahan atau ranah penegakan. Putusan MK Nomor 71/PUU-XIV/2016 merupakan putusan yang menghambat politik/kebijakan kriminal pada aspek pencegahan karena memberikan ruang kepada mantan terpidana korupsi untuk mencaonkan diri kembali dalam pemilihan kepala daerah yang merupakan jabatan publik, sehingga situasi yang demikian besar kemungkinan akan menyebabkan mantan terpidana korupsi akan melakukan kembali perbuatannya dan berdampak kepada orang lain yang merupakan pejabat publik tidak akan segan melakukan korupsi karena tidak ada efek jera yang sangat maksimal berbeda dengan sebelum adanya putusan MK аqиo yang memiliki efek kepada mantan terpidana korupsi dan orang lain yang merupakan pejabat publik agar tidak melakukan korupsi.

\section{Daftar Pustaka}

\section{Buku :}

Arief, Barda Nawawi. Bunga Rampai Kebijakan Hukum Pidana (Perkembangan Penyusunan Konsep KUHP Baru), Edisi Kedua, Cetakan Ke-3, Jakarta: Kencana, 2011

Faisal, Ilmu Hukum, Sebuah Kajian Kritis, Filsafat, Keadilan, dan Tafsir, Yogyakarta, Thafa Media, 2015

Gosita, Arif, Maslah korban kejahatan, CV Akademika Pressindo, Jakarta, 2005

Hiariej, Eddy O.S, Prinsip-prinsip Hukum Pidana. Yogyakarta, Cahaya Atma Pustaka, 2014. Junaidi, Muhammad, Ilmu Negara sebuah konstruksi ideal negara hukum. Malang, Setara Press, 2016.

Kaelan, Pendidikan Pancasila, Pendidikan Untuk Mewujudkan Nilai-nilai Pancasila, Rasa Kebangsaan, dan Cinta Tanah Air, Edisi Revisi Kesepuluh, Yogyakarta: Paradigma, 2014.

Kartasasmita, Ginandjar. Pembangunan untuk Rakyat : Memadukan Pertumbuhan dan Pemerataan, Jakarta, CIDES, 1996 
Kusumaatmadja, Mochtar. Hubungan Antara Hukum dengan Masyarakat: Landasan Pikiran, Pola, dan Mekanisme Pelaksanaan Pembaruan Hukum. Jakarta BPHN-LIPI. 1976

Muhammad, Abdulkadir. Hukum dan Penelitian Hukum, Bandung, PT Citra Aditya. 2004

Latif, Yudi. Negara Paripurna : Historisitas, Rasionalitas, dan Aktualitas Pancasila. Jakarta PT. Gramedia Pustaka Utama, 2011.

Muladi, HAM Dalam Perspektif Sistem Peradilan Pidana. Bandung, Refika Aditama, 2005

Muladi. Lembaga Pidana Bersyarat, Bandung: P.T. Alumni, 1985.

Muhammad, Bushar. Pokok-pokok Hukum Adat, Jakarta, Pradnya Paramita, 1981.

Prasetyo, Teguh. Keadilan Bermartabat Perspektif Teori Hukum. Bandung, Nusa Media, 2018.

Ravena, Dey dan Kristian, Kebijakan Kriminal Jakarta, Kencana, 2017.

Rosadi, Otong, Quo Vadis, Hukum Ekologi dan Keadilan Sosial, Dalam Perenungan Pemikiran (Filsafat) Hukum. Bantul Thafa Media, 2012.

Soekanto, Soerjono dan Sri Mamudji, Penelitian Hukum Normatif Suatu Tinjauan Singkat, Jakarta, PT Raja Grafindo Persada. 2004

Tanya, Bernard L et.al. Teori Hukum. Bantul, Genta Publishing, 2013.

Zaidan, Ali. Kebijakan Kriminal Jakarta, Sinar Grafika, 2016.

\section{Jurnal :}

Amrullah, M. Arief. Pencucian Uang dan Kejahatan Terorganisir. Jurnal Hukum. No. 22 Vol 10. Januari 2003.

Damanik, Kristwan Genova, Antara Uang Pengganti Dan Kerugian Negara Dalam Tindak Pidana Korupsi. Jurnal Masalah-masalah Hukum, Jilid 45 No. 1, Januari 2016.

Matnuh, Harpani. Law as a Tool of Social Engineering. Advances in Social Science, Education and Humanities Research, volume 147; 2017

Hanafi, Ridho Imawan, Pemilihan Langsung Kepala Daerah Di Indonesia: Beberapa Catatan Kritis Untuk Partai Politik. Jurnal Penelitian Politik Volume 11 No. 2 Desember 2014.

Hartono, Sunaryati. Kebijakan Pembangunan Hukum Jangka Panjang Tahap Kedua Jakarta majalah BPHN 1994 No 1.

\section{Internet :}

https://www.beritasatu.com/nasional/528035/icw-hukuman-bagi-kepala-daerah-korup-masihringan.

https://www.merdeka.com/politik/ini-daftar-49-mantan-koruptor-yang-maju-jadi-caleg-dipemilu-2019.html. 